\title{
Trajectories of University of Ibadan Undergraduates' Exposure to Cyber Pornography
}

\author{
Haleemah Bukola Adebayo \\ University of Ibadan \\ Usman Adekunle Ojedokun \\ University of Ibadan
}

Cyber pornography is fast gaining ground in the Nigerian cyber environment with undergraduate students among its major consumers. Against this background, this study investigated the trajectories of University of Ibadan undergraduates' exposure to cyber pornography. Containment theory was used as a theoretical framework. Data were collected from 250 respondents through surveys and in-depth interviews. Respondents' selection was achieved through a multistage sampling technique. Findings revealed that browsing for academic materials (37.0\%) and Internet surfing (35.0\%) were the major online activities predisposing respondents to cyber pornography. The majority of the respondents $(78.3 \%)$ identified sex videos and nude pictures as the most commonly encountered cyber pornographic materials. Increased sexual urge was the major effect that most of the respondents (39\%) attributed to cyber pornography. Undergraduate students need to be constantly counseled by relevant stakeholders on the danger and negative consequences associated with cyber pornography.

Keywords: cyber pornography, undergraduates, University of Ibadan, Nigeria

\section{Introduction}

The pervasiveness of leaked nude pictures, revenge porn, and pornographic movies in the Nigerian cyber environment has become a major cause for concern in recent times (Akor, 2017; Ayodele 2017; Longe et al., 2007; Okafor, Efetobor, \& Apeh, 2015). Indeed, cyber pornography is among the most common forms of online antisocial behaviors engaged in by undergraduate students in Nigeria. Generally, tertiary institution students are a major group of Internet users in Nigeria frequently consuming online pornographic materials because most of them are account holders of different social media platforms where different pornographic materials are frequently circulated (Aileru, 2016).

Cyber pornography is fast gaining ground in the Nigerian cyber environment due to the absence of any concrete law against it (Kunnuji, 2010; Okafor et al., 2015). Consequently, undergraduate students and other categories of youths are voluntarily and involuntarily becoming exposed to sexually explicit contents online. Indeed, evidence abounds in Nigeria, which indicates that the number of youths who are victims of revenge porn, like leaked nude pictures and sex videos, is increasing (Onikoyi, 2016; "Sex Video: UNIOSUN Lecturer," 2016; Udom, 2016). This trend, if not urgently reversed, is capable of negatively affecting the social, emotional and psychological wellbeing of many youths. Cyber pornography is not only capable of impacting negatively on the lifestyles of people viewing it, but it can also results in lifelong harrowing experiences or promotes suicidal 
thoughts in individuals whose nude pictures and sex videos got leaked on the Internet (Egan \& Parner, 2013; Harper and Hodgins, 2016).

The Internet has significantly globalized pornography by making it more available and accessible to different groups of Internet users in the society (Beyens \& Eggermont, 2014; Egan \& Parner, 2013; Flood, 2007; Hald \& Malamuth, 2008; Morelli, Bianchi, Baiocco, Pezzuti, \& Chirumbolo, 2017; Peter \& Valkenburg, 2006). Indeed, statistics have revealed that about $12 \%$ of the Internet is composed of pornography (Twohig, Crosby, \& Cox, 2009), while 25\% of all searches on the Web are for pornography (Ropelato, 2006). Moreover, many Internet users have also reported having accidently accessed pornographic material in cyberspace (Mitchell, Finkelhor, \& Wolak, 2003). In a study conducted on Internet pornographic materials use among university students by Boies (2002), it was discovered that $72 \%$ of male and $24 \%$ of female reported using the Internet to view pornography, with $11 \%$ of the users reported viewing sexually explicit materials once a week or more. Similarly, a study conducted by Lo and Wei (2005) among adolescent students in Taiwan revealed a relationship between adolescents' exposure to sexually explicit material and positive attitudes toward premarital and extramarital sexual relations.

Wamathai, Sirera, and Mwenje (2014) identified the major factors contributing to Internet pornography viewing among the youths to include seeking sex information, curiosity, and entertainment. Pornography as a visual (mis)representation of sexuality distorts an individual's concept of sexual relations and alters both sexual attitudes and behavior (Fagan, 2009). A study conducted by Wolak, Finkelhor, Mitchell, and Ybarra (2008) indicated that youths' involvement in online sexual activities often leads to real-life sex crimes. Equally, research has shown that Internet pornography is perceived as possibly more accessible, more explicit, and more harmful than pornography in its traditional forms (Beaver, 2000; Buzzell, 2005).

Uncontrolled exposure to cyber pornography constitutes a gateway to sex-related violence and other deviant sexual expressions like rape, bestiality, fetishism, pedophilia, or sexual masochism (Buzzell, 2005; Laier, Pawlikowski, Pekal, Schulte, \& Brand, 2013; Laier, Pekal \& Brand, 2014; Wolak et al., 2008). Apart from this, cyber pornography viewing can also result in a chaotic lifestyle because it has the tendency to lead to sexual addiction, low self-esteem, and depression in individuals involved in it (Fagan, 2009; Wamathai et al., 2014). Despite the ubiquitous nature of cyber pornographic materials and their associated physical, emotional, and psychological risks, this problem has yet to receive adequate scholarly attention in Nigeria. Against this background, this study investigated the trajectories of University of Ibadan undergraduates' exposure to cyber pornography with an aim of filling this observed void.

\section{Theoretical Framework}

This study was guided by the postulations of containment theory developed by Reckless (1961). The theory views delinquency as the interplay between two forms of control: internal (inner) and external (outer). It assumes that every individual possesses a containing external structure and a protective internal structure that buffer, protect, and insulate them against society-induced pulls and pushes toward deviant behavior. Inner containments, simply put, are "self" components and strength of one's personality, which include a good self-concept, strong ego, well-developed conscience, high sense of responsibility, and high frustration tolerance (Reckless, 1961). Outer containments refer to one's social environment and normative constraints that society and groups use to control its members. Outer containments include belonging (identification with the group), effective supervision, cohesion among group members (togetherness), opportunities for achievement, 
reasonable limits and responsibilities, alternative ways and means of satisfaction (if one or more ways are closed), reinforcement of goals, norms, values, and discipline. The theory posits that inner containments are more important than outer containments. According to it, a self-concept exists in people and is formed when they are quite young. This self-concept provides either a "good" or a "bad" image of the self and acts as a buffer to outside influences. The tendency to commit delinquent acts depends on the strength of an individual's inner and outer containments (Reckless, 1961). If the selfconcept were bad, outer social controls would have little effect on the individual and delinquency would be more likely to result. However, an individual with a good self-concept could withstand weak external social control and resist committing delinquent acts. Undergraduate students' decisions on whether to view pornographic materials whenever they come across them online are strongly dependent on the strength of their inner and outer containments.

\section{Study Area and Study Population}

University of Ibadan in Nigeria was the selected area of study. It was established in 1948, making it the first university in Nigeria. It has an annual intake of over 3,000 undergraduate students. The rationale behind the choice of University of Ibadan is predicated on the fact that it is a federal government-owned institution, therefore making it a distinct university of choice for students from diverse socioeconomic backgrounds. In addition, most of the undergraduate students of the university are active users of the Internet and are also account holders of various social media (Aileru, 2016), putting them at risk of being exposed to cyber pornography. Both female and male undergraduate students of University of Ibadan constituted the population of study. However, it was only students who were willing to share their experiences regarding voluntary and involuntary cyber pornographic exposures who were involved in the research.

\section{Methodology}

This study was descriptive and cross-sectional in design. Data collection involved the triangulation of both quantitative and qualitative methods. Specifically, copies of a set of 300 semistructured questionnaires, containing 31 distinct but interrelated questions, were administered to undergraduate students across five randomly selected faculties (60 per faculty) including the Faculty of Agriculture and Forestry, Faculty of Education, Faculty of Science, Faculty of the Social Sciences and Faculty of Technology. However, a total of 254 questionnaires, representing about 85\%, were completed. Also, to complement the quantitative data, 15 sessions of in-depth interviews (IDIs; each lasting between 45 and $60 \mathrm{~min}$ ) were conducted with some of the respondents who had unique information and experience about the study. A multistage sampling technique was used for the selection of the respondents. At the first stage, five faculties were randomly chosen from the 11 available in the University. At the second stage, each of the selected faculties was then clustered on departmental basis. Thereafter, stratified and simple random sampling techniques were adopted for the selection of students across different departments and academic levels of study. With regard to data analysis, quantitative data were subjected to both descriptive and inferential statistics involving frequency distributions, simple percentages, cross tabulation, and chi-square, while the data yielded by the IDI were analyzed through content analysis and ethnographic summaries, involving careful transcription, detailed description, and interpretation of tape-recorded data. Precisely, content analysis was used to explore and interpret emerging patterns in the data collected, while ethnographic summaries were done to further enhance data interpretation through the direct quotation of some important responses that emanated during discussions. 
A limitation of this study is that its results may not be adequately representative of the perspectives of undergraduate students of the University of Ibadan regarding their exposure to cyber pornography because male students were disproportionately represented compared with their female counterparts. However, despite this identified limitation, the contribution of this study to the existing body of knowledge cannot be overemphasized because it yielded some illuminating results on the undergraduate students' exposure to cyber pornography.

\section{Ethical Consideration}

Due to the sensitive nature of issues bordering on cyber pornography, the international standard ethics for research was strictly adhered to in this study. The consents of the respondents were sought and obtained before their participation in the research. The objectives of the study were carefully explained to them, and they were also informed of their right to voluntary participation, as well as their right to withdraw from the study at any time they deemed necessary. Moreover, participation in this study was purely voluntary, and no form of incentive or inducement was offered to the respondents. In addition, the administered questionnaire was designed in such a way that the identities of the respondents were kept anonymous. Similarly, all the IDIs were privately conducted.

\section{Results and Discussion}

The major results which emanated from this study are presented in this section. These are thematically discussed as a way of ensuring coherence and lucidity of discourse.

\section{Sociodemographic Profile of Respondents}

Table 1 depicts background information on the respondents. As evident in the table, the majority (85.4\%) was male and $14.6 \%$ were females. This imbalance in the distribution of the respondents based on sex was largely because most of the female students interacted with during data gathering declined to share their experiences on voluntary and involuntary exposure to cyber pornography.

Regarding age distribution, $66.9 \%$ of respondents were between the ages of 21 and 24 , and $21.7 \%$ were between the ages of 16 and 20 . Fewer than $12 \%$ of the respondents fell within the age range of 25-29. This distribution is typical of the age distribution of undergraduates in most universities in Nigeria. Also, $52.0 \%$ of respondents were Christian, and $48.0 \%$ were Muslim. Furthermore, most of the respondents were single (93.7\%). In addition, Table 1 shows that the distribution of the respondents based on faculty was fairly balanced: Agriculture and Forestry (19.3\%), Education (19.3\%), Science (21.7\%), Social Sciences (19.7\%), and Technology (20.1\%). Finally, most of the respondents (51.6\%) were in the 400 level, $20.5 \%$ were in the 300 level, and $13.0 \%$ were in the 100 level. 
Table 1. Sociodemographic Profile of Respondents

\begin{tabular}{lcc}
\hline Characteristics $(\boldsymbol{N}=\mathbf{2 5 4})$ & Frequency & $\mathbf{( \% )}$ \\
\hline Sex & & \\
Male & 217 & 85.4 \\
Female & 37 & 14.6 \\
Total & 254 & 100 \\
Age of students & & \\
16-20 & 55 & 21.7 \\
$21-24$ & 170 & 66.9 \\
$25-29$ & 29 & 11.4 \\
Total & 254 & 100 \\
Religion & & \\
Christianity & 132 & 52.0 \\
Islam & 122 & 48.0 \\
Total & 254 & 100 \\
Marital status & & \\
Married & 16 & 6.3 \\
Single & 238 & 93.7 \\
Total & 254 & 100 \\
Faculty & & \\
Agriculture and Forestry & 49 & 19.3 \\
Education & 49 & 19.3 \\
Science & 55 & 21.7 \\
Social Science & 50 & 19.7 \\
Technology & 51 & 20.1 \\
Total & 254 & 100 \\
Level of study & & \\
100 & 33 & 13.0 \\
200 & 28 & 11.0 \\
300 & 52 & 20.5 \\
400 & 131 & 3.9 \\
500 & 254 & 100 \\
Total & &
\end{tabular}

\section{Online Activities Predisposing Respondents to Cyber Pornography}

Information was sought on respondents' online activities predisposing them to cyber pornography to understand their pattern of exposure. The distribution of respondents based on online activities predisposing them to cyber pornography as shown in Table 2 indicates that the largest proportion (37.0\%) stated that they frequently stumbled upon pornographic items whenever they browsed for academic materials. Also, a considerable proportion (35.0\%) of the respondents identified Internet surfing, while $28.0 \%$ mentioned online music and video downloads as the online activities exposing them to pornographic materials on the cyber environment. 
Table 2. Online Activities Predisposing Respondents to Cyber Pornography

\begin{tabular}{lcc}
\hline Online Activities & Frequency & Percentage (\%) \\
\hline Browsing for academic materials & 94 & 37.0 \\
Online music and video downloads & 71 & 28.0 \\
Internet surfing & 89 & 35.0 \\
Total & 254 & 100.0 \\
\hline
\end{tabular}

The remarks of the respondents covered in the IDIs corroborated this quantitative data. One of the students interviewed said, "I often stumble on pornographic materials online whenever I try to browse for materials for my school assignments. Also, sometimes when I am downloading some stuffs on the Internet I usually come across different pornographic materials" (IDI/male/22 years/400 level/Faculty of Technology). In the words of another respondent,

At times, when I am on social media or when I am browsing for academic materials for my assignments, I frequently come across some unsolicited links and pop-up video messages. Most times, when I click on those links, I usually discover that they are either promoting nude pictures or videos. (IDI/female/21 years/400 level/Faculty of Education)

It can be deduced from these findings that a wide range of online activities are exposing University of Ibadan undergraduates to cyber pornography. The fact that most of the respondents reported coming across cyber pornographic materials while browsing for academic materials indicates that pornography is increasingly dominating the cyber environment, and it may not necessarily be website bound. The implication of these findings is that Internet users are being exposed to voluntary and involuntary viewing of pornographic materials on the cyber environment.

Consequently, some categories of Internet users, particularly young children and teenagers may be negatively impacted. These findings support the submission of Okafor et al. (2015) that young adults in Nigerian universities are among the most susceptible audience to sexually explicit content on the Internet.

\section{Internet as Inducing Respondents to Consume Cyber Pornographic Materials by Age}

The opinions of the respondents were also sought on whether the Internet is inducing them to consume cyber pornographic materials. Table 3 presents respondents' responses based on their agerange distribution.

Table 3. Internet as Inducing Consumption of Cyber Pornographic Materials by Age

\begin{tabular}{lccc}
\hline Age, years & Yes, $\boldsymbol{n} \mathbf{( \% )}$ & No, $\boldsymbol{n} \mathbf{( \% )}$ & Total, $\boldsymbol{n} \mathbf{( \% )}$ \\
\hline $16-20$ & $32(58.2 \%)$ & $23(41.8 \%)$ & $55(21.7 \%)$ \\
$21-24$ & $91(53.5 \%)$ & $79(46.5 \%)$ & $170(66.9 \%)$ \\
$25-30$ & $4(13.8 \%)$ & $25(86.2 \%)$ & $29(11.4 \%)$ \\
Total & $127(50.0 \%)$ & $127(50.0 \%)$ & $254(100.0 \%)$ \\
\hline
\end{tabular}

Note. $\chi^{2}=17.527 ; d f=2 ; p=.000$.

At the general level, the analysis in Table 3 indicates that there was no clear-cut consensus among the respondents regarding whether the Internet is inducing them to consume cyber pornography. The table indicates that $50 \%$ of the respondents believed that Internet is inducing their consumption of cyber pornographic materials, while a similar proportion (50\%) stated that it does not. A further analysis of their responses according to age range also reflects the observed disparity in their 
opinions. Unlike the majority of the respondents (86.2\%) in the age range of 25-30 who stated that the Internet does not induce them to watch pornographic materials, most of the respondents who fell between ages 21 and 24 (53.5\%) and 16 and 20 (58.2\%) reported that the Internet is motivating their consumption of cyber pornographic materials. Furthermore, despite the fact that the majorities in the age groups 21-24 and 16-20 submitted that the Internet induced their pornographic consumption, substantial proportions of these two categories (21-24 [46.5\%] and 16-20 [41.8\%]) maintained that it does not tempt them to view pornography. The recorded discrepancy in the opinions of the respondents was clearly reflected in the significant value of the chi-square statistics $\left(\chi^{2}=17.527 ; p<.05\right)$. The results of the survey were also demonstrated in the results of the IDIs conducted. One of the respondents thus stated,

Well, I will not say it (Internet) encourages everyone to view pornographic materials online. Actually, it all depends on the kind of personality of the person involved. But then, I think if any pornographic video pops up, it might actually encourage someone who is not religious to watch it. But I will say it (Internet) encourages some people to engage in cyber pornography. (IDI/female/25 years/400 level/Faculty of Technology)

Another interviewee stated,

Well, the abuse of the Internet these days has made pornographic materials rampant on different social media platforms. The social media is beginning to bring pornography to the doorstep of their users because there are different varieties of ways through which people are circulating pornographic materials. (IDI/male/25 years/400 level/Faculty of Education)

In the opinion of another respondent, "There are pornographic video pop-ups on most websites. Once one opens a website on the Internet, one is bound to come across pornographic materials" (IDI/male/26 years/400 level/Faculty of Science).

It can be inferred from these findings that although the Internet provides the avenue through which different pornographic materials get circulated, it cannot be said to be compelling users to watch pornography. This is because an individual's decision on whether to watch pornographic movies or view nude pictures online essentially depends on his or her personality. Some Internet users may ignore unsolicited pornographic materials they encounter online, while some other users of cyberspace will watch them whenever they can do so. These results corroborate the position of Flood (2007) that Internet-enabled devices are indiscriminately allowing people of all ages to encounter, consume, create, and distribute sexually explicit content. Furthermore, these findings also demonstrate the validity of one of the key propositions of containment theory which posits that the tendency to commit delinquent acts strongly depends on the strength of an individual's inner and outer containments.

\section{Commonly Encountered Pornographic Materials on the Internet}

Because pornographic materials come in varieties, such as videos, audios, pictures, and online articles, it was considered important to probe into the types of pornographic materials that respondents commonly encountered online. The statistical distribution in Table 4 shows that sex videos and nude pictures were the types of pornographic contents that most (78.3\%) of the respondents frequently encountered on the Internet. Also, close to $16 \%$ identified sex-aiding materials as the kind of pornographic materials they usually encountered online, compared to about $6 \%$ who mentioned pornographic stories. The result of the qualitative data was in tandem with the analysis of the survey. 
Table 4. Commonly Encountered Pornographic Materials on the Internet

\begin{tabular}{lcc}
\hline Types of Pornographic Materials & Frequency & Percentage (\%) \\
\hline Sex videos/nude pictures & 199 & 78.3 \\
Pornographic stories & 15 & 5.9 \\
Sex-aiding materials & 40 & 15.7 \\
Total & 254 & 100 \\
\hline
\end{tabular}

In one of the IDIs conducted, a respondent described the situation this way: "These days, I mostly come across sex videos online. Occasionally, I do stumble on nude pictures; but because I do not want to waste my data, I usually view the pictures as opposed to watching the videos" (IDI/male/25 years/400 level/Faculty of Education). In the words of another respondent, "Most times it is either sex movies or short-scene sex videos. These things (cyber pornographic materials) will just pop up unsolicited and then, I always ignore them" (IDI/female/23 years/400 level/Faculty of Technology). Another respondent said,

The fact that one is an account holder of a social media platform automatically predisposes one to encountering a lot of things (pornographic materials) whether ones like it or not. There was a time I mistakenly joined a Whatsapp group in which sex was their only subject of discuss. Eventually, I had to leave the group because they were sending me all kinds of nude pictures. (IDI/female/23 years/400 level/Faculty of the Social Sciences)

It is obvious from these findings that sex videos and nude pictures are the most common forms of pornographic materials that respondents frequently come across on the cyber environment. Another deduction that can be made from the findings is that some of the undergraduate students prefer viewing nude pictures to watching sex videos because it is relatively cheaper in terms of Internet access data consumption. The implication of this is that some respondents may be positively disposed towards cyber pornographic materials. These findings agree with the opinions of Kunnuji (2010) and Okafor et al. (2015) that pornography in various guises is one of the major emerging problems confronting the Nigerian cyberspace because of the rise in Internet penetration and unfettered access to Internet-enabled devices and media platforms.

\section{Internet Platforms Exposing Respondents to Cyber Pornography}

Internet users' online behavior often goes a long way in influencing the likelihood of their exposure to cyber pornography. Hence, respondents were asked about the Internet platforms through which they often get exposed to cyber pornography.

Table 5 indicates that Google was the cyber platform mentioned by most of the respondents (38.2\%) as exposing them to pornographic materials, but a substantial proportion (28.3\%) also identified Facebook. Other platforms mentioned by some of the respondents were YouTube (16.9\%), Bing (15.4\%), and Instagram (1.2\%). It can be deduced from this finding that rather than being involuntarily exposed to cyber pornography, some of the undergraduate students actively searched for pornographic contents on the Internet. This reasoning emanates because a substantial proportion of them identified Google and Bing as the platforms exposing them to cyber pornography. This is impossible because these two platforms (Google and Bing) are essentially search engines that do not prompt Internet users but rather respond exclusively to users' queries. According to containment 
theory, an individual with a good self-concept could withstand weak external social control and resist the tendency to committing delinquent acts, while outer social controls would have little or no effect on the inclination of an individual with a bad self-concept towards delinquency. Also, a study conducted by Longo, Brown, and Orcut (2002) has equally revealed that adolescents use the Internet for activities relating to gaining sexual knowledge and seeking/obtaining sexual satisfaction.

Table 5. Platforms Exposing Respondents to Cyber Pornography

\begin{tabular}{lcc}
\hline Internet Platforms & Frequency & Percentage (\%) \\
\hline Google & 97 & 38.2 \\
Bing & 39 & 15.4 \\
YouTube & 43 & 16.9 \\
Facebook & 72 & 28.3 \\
Instagram & 3 & 1.2 \\
Total & 254 & 100 \\
\hline
\end{tabular}

\section{Action Normally Taken When Encountered Online Pornographic Materials}

As evident in Table 6, most of the respondents (63.0\%) reported that they usually ignore pornographic materials whenever they come across them online, as opposed to $21 \%$ that disclosed that they usually watch online pornographic contents. However, less than $17 \%$ maintained that they always logout whenever they stumbled on Internet pornographic content. Further analysis done to determine if respondents' relationship status influences their disposition toward cyber pornography indicated that though most of the respondents from the two groups claimed they usually ignore online pornographic materials, a considerable proportion (35.4\%) of those in a relationship confirmed they usually watch them, and a substantial proportion (23.4\%) of those who were single claimed they normally logout altogether. The observed difference in their responses was reflected in the significant values of the chi-square $\left(\chi^{2}=29.532 ; p<.005\right)$. The outcome of the IDI further complemented the survey.

Table 6. Relationship Status and Action Normally Taken

\begin{tabular}{lcccc}
\hline $\begin{array}{l}\text { Relationship } \\
\text { Status }\end{array}$ & Watch It & Log Out & Ignore It & Total \\
\hline In a relationship & $34(35.4 \%)$ & $4(4.2 \%)$ & $58(60.4 \%)$ & $96(37.8 \%)$ \\
$\begin{array}{l}\text { Not in a } \\
\text { relationship }\end{array}$ & $19(12.0 \%)$ & $37(23.4 \%)$ & $102(64.6 \%)$ & $158(62.2 \%)$ \\
Total & $53(20.9 \%)$ & $41(16.1 \%)$ & $160(63.0 \%)$ & $254(100.0 \%)$ \\
\hline
\end{tabular}

Note. $\chi^{2}=29.532 ; d f=2 ; p=.000$.

An interviewee described the action he normally takes this way:

In the past, I have actually watched pornographic video online, but it does not freak me any longer. These days, whenever I come across it online, I always overlook it. However, I still do click on and view nude pictures whenever they pop-up. (IDI/male/25 years/400 level/Faculty of Education)

Another interviewee stated, "In the time past, I always watch it (cyber pornographic video), but presently I even try as much as possible to avoid it. When I come across it, I will just close the page" (IDI/female/24 years/400 level/Faculty of the Social Sciences). In the words of another respondent, "I 
do check it [cyber pornographic material] whenever I come across it on the Net. That is all I will say, I will not say more than that" (IDI/male/25 years/400 level/Faculty of the Social Sciences).

It is clear from these findings that although most of the respondents generally ignore cyber pornographic materials whenever they come across them, undergraduate students who were in a relationship seem to be more favorably disposed toward watching them than those who were single. This difference in respondents' dispositions may be explained as resulting from the fact that those who are in a relationship are most likely to be engaging in sexual relations with their partners. Therefore, they may be more interested in gaining "new knowledge" about sexual acts by watching pornography. These findings demonstrate the relevance of containment theory, which opined that the likelihood of an individual engaging in delinquency is closely dependent on the strength of his or her internal and external controls. Mitchell et al. (2007) have also observed that there is an increase in the number of youths who are intentionally or accidentally encountering pornographic material online.

\section{Effects of Cyber Pornography on Respondents' Sexual Behavior}

Studies have established that youth's exposure to pornographic contents often have negative consequences on them (Krauss \& Russell, 2008; Poulsen, Busby, \& Galovan, 2013; Schneider, 2000). Therefore, it was considered imperative to investigate the effects of cyber pornography on respondents' sexual behavior. Table 7 presents the result of the analysis.

Table 7. Effects of Cyber Pornography on Respondents' Sexual Behavior

\begin{tabular}{lcc}
\hline Effects of Cyber Pornography & Frequency & Percentage (\%) \\
\hline Masturbation & 92 & 36.2 \\
Increased sexual urge & 99 & 39 \\
Mind control (addiction) & 43 & 16.9 \\
Undecided & 20 & 7.9 \\
Total & 254 & 100 \\
\hline
\end{tabular}

As shown in Table 7, most of the respondents (39\%) submitted that their exposure to cyber pornography increased their sexual urges, while a substantial proportion (36.2\%) claimed they often indulged in masturbation. In addition, about $17 \%$ of the respondents disclosed that they are becoming addicted to cyber pornography because it is frequently dominating their thoughts. The implication of this finding is that the continual viewing of cyber pornographic materials has the tendency to negatively impact the physical and emotional wellbeing of some of the respondents. Cyber pornography encourages the act of masturbation and increases sexual urges in respondents, which could lead to rape, low self-esteem, and uncontrolled libido. Wolak et al. (2008) have also articulated that youths' involvement in online sexual activities often leads to real-life sex crimes. Similarly, Harper and Hodgins (2016) have also pointed out that several reports indicate that Internet pornography is already becoming problematic for some individuals.

\section{Conclusion}

The central concern of this study was the trajectories of University of Ibadan undergraduates' exposure to cyber pornography. Generally, it was established that pornography is increasingly dominating the Nigerian cyber environment. The three major online activities predisposing University of Ibadan undergraduates to cyber pornography include browsing for academic materials, 
surfing the Internet, and downloading online music/video. Also, sex videos and nude pictures were the most commonly encountered pornographic materials on the Internet. Uncontrolled exposure to cyber pornography is capable of negatively impacting the wellbeing of youths and other Internet users. Therefore, it is important for the undergraduate students to be constantly enlightened and counseled on the danger and negative consequences associated with pornography in general and cyber pornography in particular. Relevant stakeholders, such as parents, school management, the media, the National Orientation Agency, and religious bodies, can take on this responsibility. Also, there is the need for relevant agencies of government, particularly the Nigerian Communications Commission and Broadcasting Organisation of Nigeria, to collaborate with the major Internet service providers operating in the country to design effective mechanisms through which pornographic Internet contents circulating the Nigerian cyber environment can be significantly reduced. Similarly, it is imperative for the Federal Government of Nigeria to formulate a specific law that will prescribe stiff punishment for blackmailers using the Internet to leak and circulate people's nude pictures and sex videos. Finally, undergraduate students should be encouraged to install Internet content-filtering software and to reduce the risk of involuntary exposure to cyber pornographic materials whenever they are online.

\section{References}

Aileru, M. M. (2016). Social media and cyber victimization experience of University of Ibadan undergraduate students (Unpublished master's thesis). Department of Information Science, University of Ibadan, Ibadan, Nigeria.

Akor, L. (2017). The social media, deviance and youths in Nigeria. In P. N. Ndubueze (Ed.), Cyber criminology and technology-assisted crime control: A reader (pp. 47-64). Zaria, Nigeria: Ahmadu Bello University Press.

Ayodele, J. O. (2017). Perception of online deviance and social media censorship among undergraduates. In P. N. Ndubueze (Ed.), Cyber criminology and technology-assisted crime control: A reader (pp. 65-88). Zaria, Nigeria: Ahmadu Bello University Press.

Beaver, W. (2000). The dilemma of internet pornography. Business and Society Review,105, 373-382.

Beyens, I., \& Eggermont, S. (2014). Prevalence and predictors of text-based and visually explicit cybersex among adolescents. Young: The Nordic Journal of Youth Research, 22, 43-65.

Boies, S. C. (2002). University students' uses of and recreations to online sexual information and entertainment: Links to online and offline sexual behaviour. Canadian Journal of Human Sexuality, 11, 77-89.

Buzzell, T. (2005). The effects of sophistication, access and monitoring on use of pornography in three technological contexts. Deviant Behavior, 26, 109-132.

Egan, V., \& Parner, R. (2013). Dirty habits? Online pornography use, personality, obsessionality, and compulsivity. Journal of Sex \& Marital Therapy, 39, 394-409. doi:10.1080/0092623X.2012.710182

Fagan, P. F. (2009). The effects of pornography on individuals, marriage, family and community. Washington, DC: Family Research Council. Retrieved from https://www.frc.org/issuebrief/the-effects-of-pornography-on-individuals-marriage-familyand-community

Flood, M. (2007). Exposure to pornography among youth in Australia. Journal of Sociology, 43, $45-60$. 
Hald, G. M., \& Malamuth, N. M. (2008). Self-perceived effects of porn consumption. Archives of Sexual Behavior, 37, 614-625.

Harper, C., \& Hodgins, D. C. (2016). Examining correlates of problematic internet pornography use among university students. Journal of Behavioural Addictions, 5, 179-191.

Krauss, S., \& Russell, B. (2008). Early sexual experiences: The role of internet access and sexually explicit material. CyberPsychology \& Behavior, 11, 162-168.

Kunnuji, M. (2010). The internet and adolescent sexuality in Lagos metropolis, Nigeria: Influence of online sexual activities on real life sexual behaviour of adolescents. Berlin, Germany: Lambert Academic Publishing.

Laier, C., Pawlikowski, M., Pekal, J., Schulte, F. P., \& Brand, M. (2013). Cybersex addiction: Experienced sexual arousal when watching pornography and not real-life sexual contacts makes the difference. Journal of Behavioral Addictions, 2, 100-107.

Laier, C., Pekal, J., \& Brand, M. (2014). Cybersex addiction in heterosexual female users of internet pornography can be explained by gratification hypothesis. Cyberpsychology, Behavior and Social Networking, 17, 505-511.

Lo, V. H., \& Wei, R. (2005). Exposure to internet pornography and Taiwanese adolescents' sexual attitudes and behavior. Journal of Broadcasting and Electronic Media, 49, 221-237.

Longe, O. B., Chiemeke, S. C., Onifade, O. F. W., Balogun, F. M., Longe, F. E., \& Otti, V. U. (2007). Exposure of children and teenagers to internet pornography in southwestern Nigeria: Concerns, trends and implications. Journal of Information and Technology Impact, 7, 195212.

Longo, R. E., Brown, S. M., \& Orcut, D. P. (2002). Effects of internet sexuality on children and adolescents. In A. Cooper (Ed.), Sex and internet: A guide book for clinicians. New York, NY: Brunner-Routledge.

Mitchell, K. J., Finkelhor, D., \& Wolak, J. (2003). The exposure of youth to unwanted sexual material on the Internet: A national survey of risk, impact, and prevention. Youth \& Society, 34, 330358. doi:10.1177/0044118X02250123

Mitchell, K. J., Wolak, J., \& Finkelhor, D. (2007). Trends in youth reports of sexual solicitations, harassment and unwanted exposure to pornography on the internet. Journal of Adolescent Health, 40, 116-126.

Morelli, M., Bianchi, D., Baiocco, R., Pezzuti, L \& Chirumbolo, A. (2017). Sexting behaviors and cyber pornography addiction among adolescents: The moderating role of alcohol consumption. Sexuality Research and Social Policy, 14, 113-121, doi: 10.1007/s13178-0160234-0

Okafor, C. O., Efetobor, O. E., \& Apeh, A. C. (2015). An evaluation of the correlation between internet pornography and the sexual behaviour of the Nigerian undergraduates. African and Global Perspectives, 1, 1-14.

Onikoyi, A. (October 2016). Third sex tape of Miss Anambra may surface soon. Vanguard. Retrieved from https://www.vanguardngr.com/2016/10/third-sex-tape-miss-anambra-may-surface-soonsource-2/

Peter, J., \& Valkenburg, P. M. (2006). Adolescents' exposure to sexually explicit online material and recreational attitudes toward sex. Communication Research, 56, 639-660. 
Poulsen, F. O., Busby, D. M., \& Galovan, A. M. (2013). Pornography use: Who uses it and how it is associated with couple outcomes. Journal of Sex Research, 50, 72-83.

Reckless, W. C. 1961. A new theory of delinquency and crime. Federal Probation, 25, 42-46.

Ropelato, J. (2006). $2006 \& 2005$ U.S. pornography industry revenue statistics. Retrieved from http://internet-filter-review.toptenreviews.com/internetpornographystatistics.html

Schneider, J. P. (2000). A qualitative study of cybersex participants: Gender differences, recovery issues, and implications for therapists. Sexual Addiction and Compulsivity, 7, 249-278.

Sex video: UNIOSUN lecturer accuses former colleague, others of blackmail. (2016, August 13). Punch. Retrieved from https://punchng.com/sex-video-uniosun-lecturer-accuses-formercolleague-others-blackmail/

Twohig, M. P., Crosby, J. M., \& Cox, J. M. (2009). Viewing internet pornography: For whom is it problematic, how, and why? Sexual Addiction \& Compulsivity, 16, 253-266.

Udom, E. (2016 November 13). OAU graduate arrested over alleged extortions using nude ladies pictures. Independent. https://independent.ng/oau-graduate-arrested-over-alleged-extortionsusing-nude-ladies-pictures/

Wamathai, A., Sirera, M. A. M., \& Mwenje, M. (2014). Prevalence and factors contributing to pornography viewing among male students in selected universities in Kenya. Journal of Humanities and Social Sciences, 19, 1-7.

Wolak, J., Finkelhor, D., Mitchell, K., \& Ybarra, M. L. (2008). Online "predators" and their victims: Myths, realities, and implications for prevention and treatment. American Psychologist, 63, 111-128.

The Journal of Social, Behavioral, and Health Sciences is an open-access, peer-reviewed, online interdisciplinary journal focusing on research findings that address contemporary national and international issues. Its objectives are to (a) encourage dialogue between scholars and practitioners in the social, behavioral, and health sciences that fosters the integration of research with practice; (b) promote innovative models of interdisciplinary collaboration among the social, behavioral, and health sciences that address complex social problems; and (c) inform the relationship between practice and research in the social, behavioral, and health sciences.

Walden University Publishing: http://www.publishing.waldenu.edu 